American Journal of Environmental Sciences 4 (6): 595-601, 2008

ISSN 1553-345X

(C) 2008 Science Publications

\title{
A Putative Serine protease from Larval Midgut of Red Palm Weevil Rhynchophorus ferrugineus (Olivier) (Coleoptera: Curculionidae): Partial Purification and Biochemical Characterization
}

\author{
Ahmed Al Jabr AND Mahmoud Abo-El-Saad \\ Faculty of Agriculture and Food Sciences, King Faisal University, P.O. Box 420, \\ Hofuf, Al-Hassa 31982, Saudi Arabia
}

\begin{abstract}
A putative serine protease was isolated and partially purified from larval midgut of red palm weevil (RPW), Rhynchophorus ferrugineus (Olivier) using anion exchange chromatography, DE-52. Sodium dodecyl sulfate polyacrylamide gel electrophoresis (SDS-PAGE) of this protease showed that the major band has a molecular weight of approximately $24 \mathrm{kDa}$ corresponding to the same molecular weight of mammalian trypsin. In addition, zymography analysis of the protease showed a single band corresponding to the same molecular weight has been measured by SDS-PAGE. Highest specific activity measured by radial diffusion of the enzyme into a casein-containing gel was achieved in $0.5 \mathrm{M}$ $\mathrm{NaCl}$ eluate. The enzyme was characterized at different $\mathrm{pH}$, substrate concentrations and various time intervals. The optimum conditions for proteolytic activity were achieved at $\mathrm{pH} 9.5$ and $0.1 \mathrm{mg}$ casein as substrate per $\mathrm{mL}$. Furthermore, the highest activity was revealed after $28 \mathrm{hrs}$ at room temperature. Moreover, soybean trypsin inhibitor dramatically inhibits the caseinolytic activity by 70 and $100 \%$ at 10 and $25 \mu \mathrm{g}$ respectively.
\end{abstract}

Key words: Trypsin-Like Enzyme (TLE), Rhynchophorus ferrugineus, trypsin inhibitor, radial diffusion, proteases

\section{INTRODUCTION}

Red palm weevil (RPW), Rhynchophorus ferrugineus, invaded Qatif in Eastern region of Saudi Arabia on 1987. RPW has expanded its range very rapidly $^{[1-3]}$. It causes sever damage to date palms and threat the dates industry. In the region, RPW control management is based mainly on the use of synthetic insecticides, which besides increasing production cost, cause environmental hazards. Therefore, development of an environmental friendly control method is a major goal of researchers in pest control. The expression of anti-metabolic proteins in transgenic plants is a quite attractive strategy to protect date palm trees from RPW. One way to do this is to incorporate inhibitors into date palm genome. In order to do this, however, it is important to identify the target digestive enzyme from the midgut of the insect to ensure successful implication of such strategy. To achieve this objective, biochemical characterization of such enzyme should be conducted.

The proteinase showed different sensitivities to inhibition by plant protein protease inhibitors, which were effective in protecting exogenous proteins from digestion by gut extracts ${ }^{[4]}$.
Plant-derived proteinase inhibitors are of a particular interest because they are part of the plant natural defense system against predation. Many insect species possess serine-type proteinases, such as trypsinlike enzyme, in their digestive system for digestion of food proteins ${ }^{[5]}$. Previous studies of the effects of dietary proteinase inhibitor, either artificially introduced into defined diets or already present in plant tissues, have shown that these proteinase inhibitors can be detrimental to the growth and development of a wide range of insects ${ }^{[6-7]}$. When foreign plant proteinase inhibitor genes were introduced into tobacco plants, the production of proteinase inhibitor at relatively high levels made the transgenic tobacco plants resistant to typical tobacco insect pests ${ }^{[8-9]}$. Recent progress in gene transfer technology makes it possible to produce new rice cultivars by introducing agronomically useful genes into rice ${ }^{[10]}$. Potato protease inhibitor II gene was successfully introduced into several rice varieties and was stably inherited in four successive generations of the transgenic rice plants. More importantly, transgenic rice plants showed increased resistance to a major rice insect pest ${ }^{[11-12]}$. The present study is focused on isolation and characterization of TLE from RPW. This

Corresponding Author: Ahmed Al Jabr, Faculty of Agriculture and Food Sciences, King Faisal University, P.O. BOX 420, Hofuf, Al-Hassa 31982, Saudi Arabia 
finding will provide an important information to pave the way for transferring specific insecticidal proteinase inhibitor gene in palm trees.

\section{MATERIALS AND METHODS}

Insects: Fourth instar larvae of $R$. ferrugineus were collected from infected palm trees at AL-Hass Oasis, Saudi Arabia. Chemicals and Reagents. Trypsin (type 1 from bovine pancreas), soybean trypsin inhibitor, casein and bovine serum albumin (BSA) were obtained from Sigma Co. Purified Agar from DIFCO, Trypan blue and Thiomersal from BDH. Ion exchange DE-52 was obtained from Whatman Co.

\section{Preparation of midgut extract from $R$. ferrugineus larvae: Larvae were anesthetized by exposing to diethyl ether for few seconds, then dissected and midguts were taken out in $20 \mathrm{mM}$ Tris- $\mathrm{HCl}, \mathrm{pH} 7.4$ followed by washing several times by the same buffer. The fat tissues were also removed by small brush, a total of 20-30 cleaned midguts of the fourth instar of $R$. ferrugineus were homogenized by electrical homogenizer in $20 \mathrm{~mL}$ ice-cold homogenization buffer containing $20 \mathrm{mM}$ Tris- $\mathrm{HCl} \mathrm{pH}$ 7.4, $5 \mathrm{mM}$ EDTA, 5 $\mathrm{mM}$ EGTA and $2 \mathrm{mM}$ 2-mercaptoethanol. The homogenate was filtrated through double layer of cheesecloth, then centrifuged at $10000 \mathrm{xg}$ for $20 \mathrm{~min}$ at $4 \mathrm{oC}$ as described by ${ }^{[13]}$. The clear supernatant was kept for the next step of the enzyme purification.}

Partial purification of a TLE: Seventeen milliliters of the crude homogenate of larva midguts $\left(10 \mathrm{mg} \mathrm{mL}^{-1}\right)$ were applied onto $8 \mathrm{~mL}$ packed column chromatography of DE-52, anion exchange has been previously equilibrated by buffer A $\quad(20 \mathrm{mM}$ Tris$\mathrm{HCl} \mathrm{pH} 7.4,5 \mathrm{mM}$ EDTA, $5 \mathrm{mM}$ EGTA and $2 \mathrm{mM} 2-$ mercaptoethanol). The column was washed by $10 \mathrm{~mL}$ of buffer A then, the bound proteins were eluted stepwise by $10 \mathrm{~mL}$ of $0.3,0.5$ and $1.0 \mathrm{M} \mathrm{NaCl}$ in buffer A. Each fraction was tested for the activity of midgut trypsin-like enzyme as described by ${ }^{[13]}$.

Preparation of the agar-substrate gel plates: Agar gels were prepared using $2 \%$ Noble agar in buffer containing $(0.1 \mathrm{M}$ Tris- $\mathrm{HCl}, \mathrm{pH} 7.4,0.9 \% \mathrm{NaCl}$ and 0.01 thiomersal as a microbial agent. The agar was mixed with $0.2 \mathrm{~mL}$ of $1 \%$ trypan blue, dissolved in water over a steam bath and cooled to $50-60{ }^{\circ} \mathrm{C}$. Casein substrate was mixed thoroughly with $10 \mathrm{~mL}$ milted agar in the final concentration $0.1 \mathrm{mg} \mathrm{mL}^{-1}$ or otherwise indicated. The agar-substrate were added in Petri dishes and allowed to cool and solidify. After solidification of the gel, 4-6 wells were punched in gels with $0.4 \mathrm{~cm}$ diameter and 0.3 depth. The center agar of the wells were removed by gentle suction using a Pasteur pipette. The wells were filled with $10-50 \mu \mathrm{L}$ of the tested enzyme alone or mixed with specific protease inhibitors.

Assessment of the proteolytic activity: Crude or partially purified trypsin-like enzyme $(20-50 \mu \mathrm{g})$ were loaded in the wells. After $24 \mathrm{hrs}$ at room temperature, the resultant caseinolytic zones around the wells were enhanced and stopped by flooding the gels with $3 \%$ acetic acid. The radial diffusion diameter were measured and the enzyme activity calculated as described by ${ }^{[14]}$.

SDS-gel electrophoresis: Electrophoresis was performed in $12 \%$ polyacrylamide gel as described by $^{[15]}$. Preparation of samples and zymograms of protease activity were done according to ${ }^{[16-17]}$. Electrophoresis was performed for $60 \mathrm{~min}$ at constant voltage of $100 \mathrm{~V}$ per gel at 5oC. After elecrophoresis, the gels were placed in $50 \mathrm{mM}$ Tris- $\mathrm{HCl}$ containing $2.5 \%$ (v/v) Triton $\mathrm{X}-100$ for $30 \mathrm{~min}$ at room temperature $^{[18]}$, then washed and incubated in substrate solution $(2 \% \mathrm{w} / \mathrm{v}$ trypsin in $20 \mathrm{mM}$ Tris- $\mathrm{HCl} \mathrm{pH} \mathrm{8.5)}$ for $30 \mathrm{~min}$ at $50 \mathrm{C}$ with gentle agitation. Then, the gel was transferred for $90 \mathrm{~min}$ to the same solution at $37 \mathrm{oC}$ without agitation. Finally, the gel was washed and proteolysis was stopped by transferring it into $12 \%$ TCA, prior to staining with $0.1 \%(\mathrm{w} / \mathrm{v})$ coomassie brilliant blue R-250 in methanol-acetic acid-water (35:10:55). Distaining was done in methanol-acetic acid-water (35:10:55).

Protein determination: Protein concentrations were measured using a Bio-Rad protein assay kit based on the method of ${ }^{[19]}$, with BSA as standard.

\section{RESULTS AND DISCUSSION}

Partial purification of TLE using anion exchange column chromatography, DE-52: Crude enzyme from larval midguts of $R$. ferrugineus has been partially purified using anion exchange chromatography, DE-52 equilibrated in buffer A (Fig. 1) When comparing the amount of eluted proteins from the column, most bound proteins emerged in fraction $0.3 \mathrm{M} \mathrm{NaCl}$ eluate which have $7.13 \mathrm{mg}$ eluted protein $/ \mathrm{mL}$. However, the highest specific activity and low amount proteins $\left(0.9 \mathrm{mg} \mathrm{mL}^{-1}\right)$ have been observed in fraction $0.5 \mathrm{M} \mathrm{NaCl}$ eluate, with a 42.1 purification fold (Table 1). 


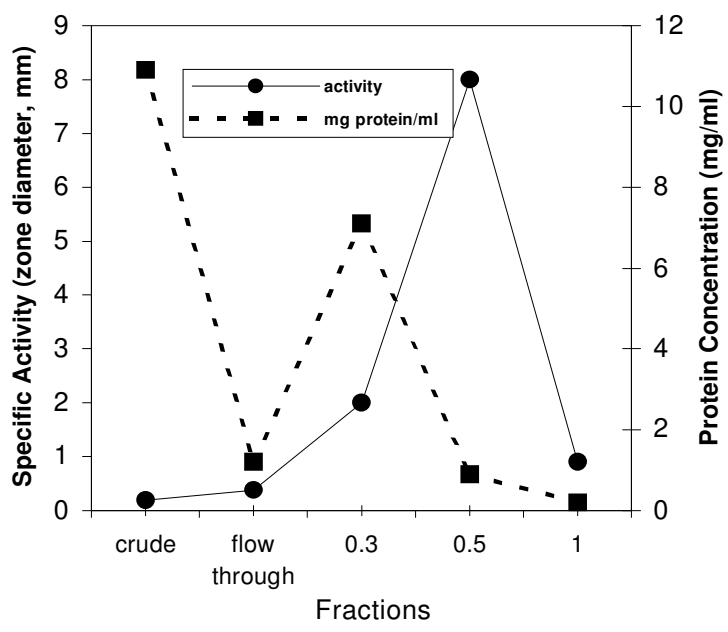

Fig. 1: Activity and protein concentration of different fractions of TLE isolated from Rhynchophorus ferrugineus midgut and partially purified by DE-52 anion exchange chromatography

Table (1): Partial purification of TLE from larval midguts of RPW

\begin{tabular}{|c|c|c|c|c|}
\hline Function & $\begin{array}{l}\mu \mathrm{g} \\
\text { protein/ } \\
\text { Well }\end{array}$ & $\begin{array}{l}\text { Zone } \\
\text { diameter } \\
(\mathrm{mm})\end{array}$ & $\begin{array}{l}\text { Specific } \\
\text { activity } \\
\mathrm{mm} / \mu \mathrm{g} \\
\text { protein }\end{array}$ & $\begin{array}{l}\text { purification } \\
\text { (fold) }\end{array}$ \\
\hline Crude & 100 & 19 & 0.19 & 1 \\
\hline \multicolumn{5}{|l|}{ DE-52 fractions: } \\
\hline Flow through & 60 & 23 & 0.39 & 2 \\
\hline $0.3 \mathrm{M} \mathrm{NaCl}$ eluate & 10 & 20 & 2.0 & 10.5 \\
\hline $\mathrm{M} \mathrm{NaCl}$ eluate & 2 & 16 & 8.0 & 42.1 \\
\hline 1.0 M NaCl eluate & 20 & 18 & 0.9 & 4.7 \\
\hline
\end{tabular}

Comparison of TLE and Trypsin activities and their molecular mass: Activity of both enzymes, TLE from $R$. ferrugineus and bovine trypsin by radial diffusion analysis was performed on casein containing agar. The enzymatic activity for partially purified midgut enzyme showed that the caseinolytic zone diameter was almost similar to that activity for highly purified mammalian trypsin (Fig. 2A). SDS-PAGE analysis showed that partially purified midgut enzyme have a molecular weight of approximately $24 \mathrm{kDa}$. (lane 2, in Fig. 2B) which relatively corresponding to same molecular weight of purified mammalian trypsin (lane 1 Fig. 2B). This result was in agreement with those reported by ${ }^{[20]}$ who identify TLE from larval midgut of the gypsy moth L. dispar L. with a molecular weight in the same range. Furthermore, endoproteases from larval midgut of $\mathrm{S}$. littoralis also have a molecular weight of $24 \mathrm{kDa}^{[20]}$. However, SDS-PAGE analysis showed that partially purified midgut enzyme have other minor bands over $24 \mathrm{kDa}$. (lane 2, in Fig. 2B). To see wether these bands have proteolytic activity or not, we

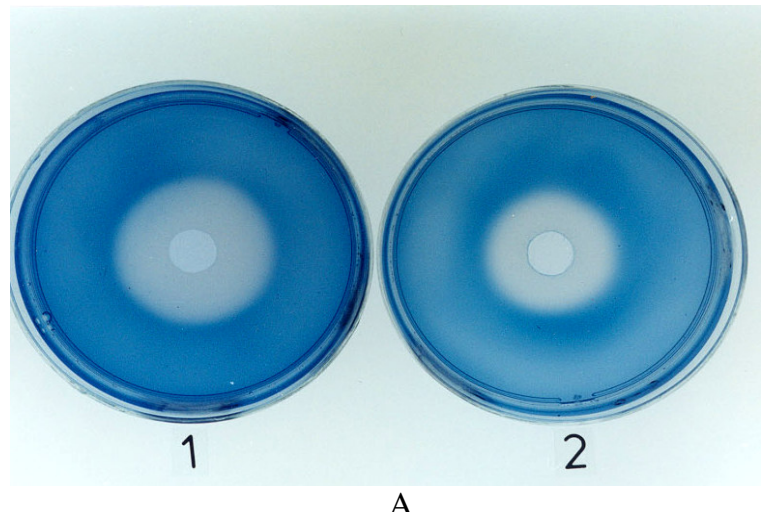

A

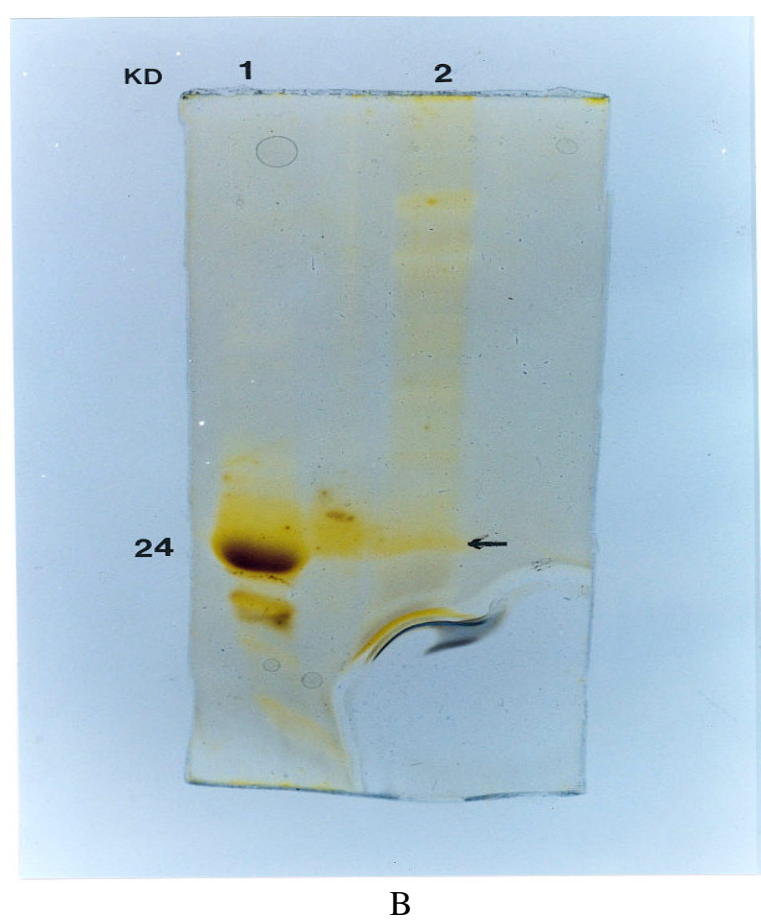

Fig. 2: (A) Activity of purified pancreatic trypsin (zone 1) and partially purified TLE isolated from larval midgut of RPW (zone 2). The assay was performed by radial diffusion analysis for both enzyme at concentration $10 \mu \mathrm{g}$ well $^{-1}$ as described under Materials and Methods. (B) SDS-PAGE analysis of both lane 2, partially purified TLE isolated from larval midgut of RPW of $(2 \mu \mathrm{g})$. The gel was stained using silver staining technique, which is more sensitive than coomassie blue

extended our analysis using SDS-PAGE zymographgy which is a simple, sensitive and functional assay for analyzing proteolytic activity. SDS-PAGE zymography 


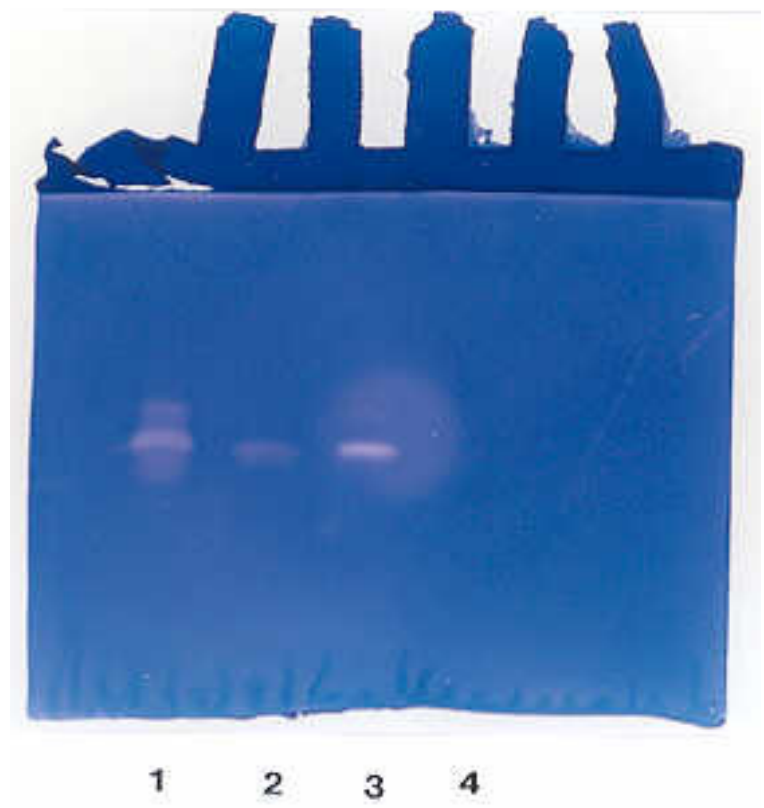

Fig. 3: Substrate-SDS-PAGE of partially purified TLE from $\mathrm{R}$. ferrugineus compared to highly purified mammalin trypsin. Lane $1,2 \mu \mathrm{g}$ trypsin, lane $2,2 \mu \mathrm{g}$ trypsin incubated with $5 \mu \mathrm{g}$ soybean trypsin inhibitor for 10 at room temperature, $3,2 \mu \mathrm{g}$ partially purified TLE from $R$. ferrugineus and lane $4,2 \mu \mathrm{g}$ partially purified TLE from R. ferrugineus incubated with $5 \mu \mathrm{g}$ soybean trypsin inhibitor for 10 at room temperature

(Fig. 3, lane 3) showed no band on the gel having proteolytic activity except $24 \mathrm{kda}$ which corresponding to the proteolytic activity band of mammalian trypsin (Fig. 3 lane 1). By other word the major band of partially purified midgut enzyme at $24 \mathrm{kda}$ has a proteolytic activity, while other minor bands had no activity. Moreover, the soybean trypsin inhibitor on SDS-PAGE zymography strongly inhibits both proteolytic activity (Fig. 3, lane 2 and 4).

Optimum pH for the TLE: The optimum $\mathrm{pH}$ value for the enzyme activity was estimated by comparing caseinolytic zones created by partially purified enzyme at different $\mathrm{pH}$ 6.5, 7.5, 8.5, 9.5, 10.5 and 11.5. As shown in Fig. 4, the optimum $\mathrm{pH}$ for this enzyme was observed at $\mathrm{pH}$ 9.5. This estimation was consistent with those results reported by ${ }^{[22]}$ and Abo-El-Saad ${ }^{[13]}$ who reported an optimum pH's was 10.5 and 10 for the activity of midgut trypsin from Manduca sexta L.and S.littoralis, respectively.

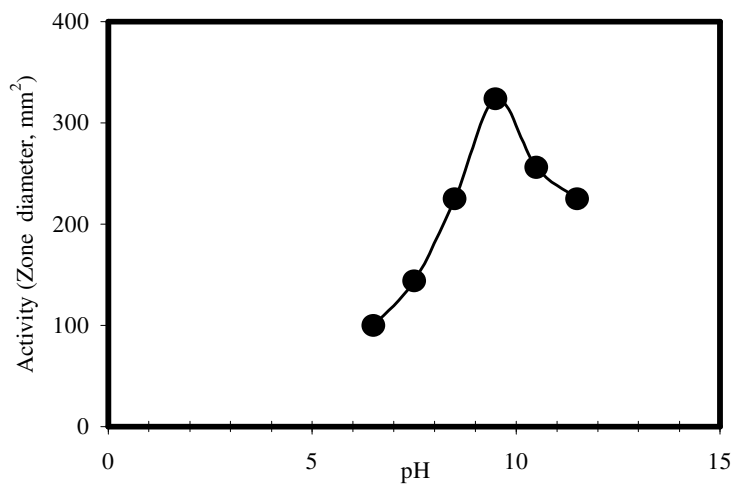

Fig. 4: Effect of various $\mathrm{pH}$ values on the activity of partially purified Rhynchophorus ferrugineus larval midgut TLE

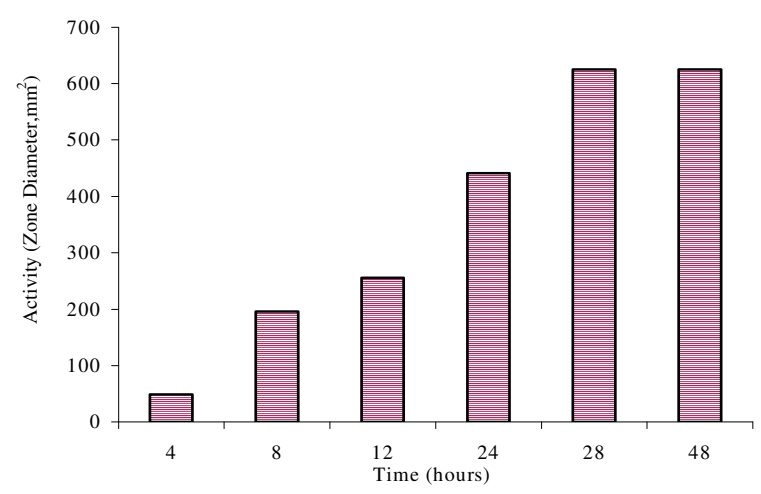

Fig. 5: Time course of the activity of TLE isolated from larval midgut of Rhynchophorus ferrugineus and partially purified by DE-52 anion exchange chromatography. The assay was performed at enzyme concentration $10 \mu \mathrm{g} /$ well of fraction 0.5 $\mathrm{M} \mathrm{NaCl}$ eluate

Serine proteases have been identified in extract from the digestive tracts of insects from many families $^{[23]}$ and protease inhibitors inhibit many of these enzymes. In the order lepidoptera, which includes a number of crop pests, the $\mathrm{pH}$ optima of the guts are in the alkaline range of $9-11^{[13]}$ where serine proteases are most active. Since, the present data have been showed that the optimum $\mathrm{pH}$ of the TLE was 9.5, suggesting that the TLE possesses similar characterizations of other insect serine proteases.

Time-course for TLE activity: The activity of TLE enzyme at different time intervals of 4, 8, 12, 24, 28 and $48 \mathrm{~h}$ were shown in Fig. 5. Radial diffusion analysis of the enzymatic activity for midgut enzyme 
Am. J. Environ. Sci., 4 (6): 595-601, 2008

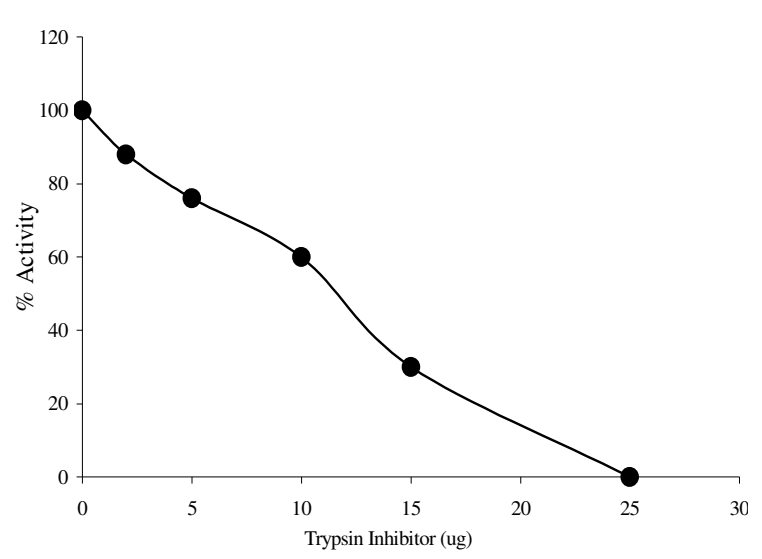

Fig. 6: Inhibition of the TLE activity from Rhynchophorus ferrugineus by different concentrations of soybean trypsin inhibitor

showed that the caseinolytic zone diameter dramatically increased to reach maximum activity at $28 \mathrm{~h}$. Our data are consistent with previous study on immunoradial diffusion in which the optimum time was $24 \mathrm{~h}^{[14]}$.

Inhibition of the enzymatic activity by specific inhibitor: To further characterize this TLE from larval midgut of $R$. ferrugineus, we extended our analysis using a specific soybean trypsin inhibitor for this enzyme. The inhibitor was found to be strongly effective on the activity of the enzyme as shown in Fig. 6. Fifteen and twenty five micrograms of the inhibitor dramatically inhibit proteolytic activity of the enzyme by $70 \%$ and $100 \%$ respectively. Many insect species secrete midgut proteinases that can be inhibited by certain protease inhibitors as described by ${ }^{[13]}$ who isolated the enzyme from midgut of S. littoralis and he found that the enzyme was strongly inhibited by trypsin inhibitor. Alkaline serine proteinase activity corresponding to trypsin was effectively inhibited by certain protease inhibitors such as benzamidine, leupeptin, chymostatin, antipain, and aprotinin ${ }^{[21]}$.

Optimum temperature and substrate concentrations for the TLE: To further characterize this TLE from larval midgut of $R$. ferrugineus, we extended our analysis to find out the optimal temperatures and substrate concentrations for TLE activity. As shown in Fig. 7 enzyme activity was increased by increasing temperatures to reach maximal activity at $30^{\circ} \mathrm{C}$. However, the results revealed that no significant effect of the temperatures in the range of $30-40^{\circ} \mathrm{C}$. In addition, titration by casein concentrations with fixed amount of enzyme (10-20 $\mu \mathrm{g})$ showed that the enzyme activity

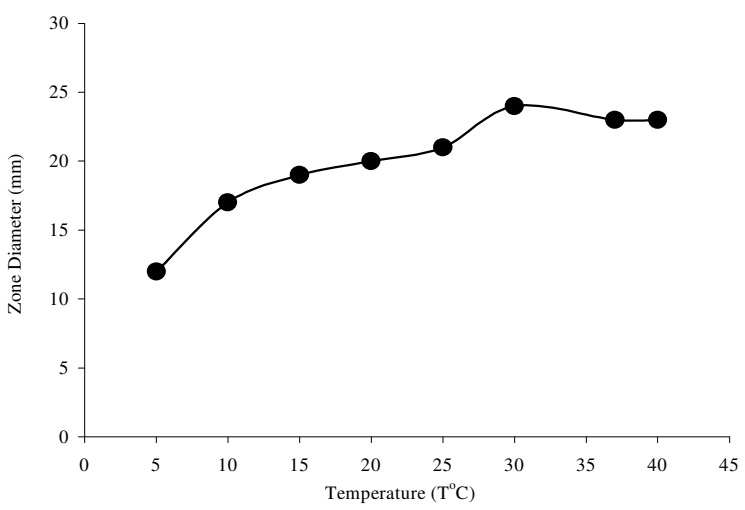

Fig. 7: Effect of various temperatures on the activity of the TLE from Rhynchophorus ferrugineus, 0.5 $\mathrm{M} \mathrm{NaCl}$ eluate of the anion exchange chromatography, DE-52

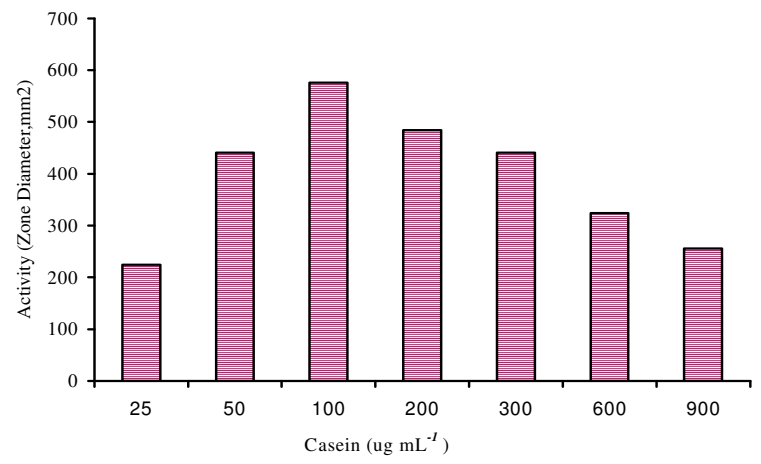

Fig. 8: Hydrolysis of various concentrations of casein as a substrate by partially purified TLE from Rhynchophorus ferrugineus

was increased by increasing casein concentration to reach maximal activity at $100 \mu \mathrm{g}$ casein/mL. However, the activity was decreased by $200 \mu \mathrm{g}$ casein/mL up to $900 \mu \mathrm{g}$ casein/mL Fig. 8.

In order to avoid further hazards resulting from extensive use of chemical pesticides integrated pest management, has been developed as alternative strategy. Integrated pest management combines cultural, chemical and biological control with ecology. Furthermore, expression of anti-metabolic proteins in transgenic plants is a quite attractive strategy to protect date palm trees from RPW. One way to do this is to incorporate protease inhibitors into the genome of date palm. In order to do this, however, it is important to identify the target digestive enzyme from the midgut of insect to ensure successful implication of such strategy. To achieve this objective, biochemical characterization of such enzyme has been conducted. 
Proteinase inhibitors have been considered as natural control agents against herbivorous insects, because they reduce proteolytic enzyme activity and affect larval development of a number of different species of Coleoptera and Lepidoptera ${ }^{[4,8]}$. However, not all species development are susceptible to proteinase inhibitors. Accordingly, our study aimed to isolate and characterize the TLE from RPW and to ensure that the TLE is inhibited by proteinase inhibitor.

Difficulty of early detecting RPW infestation is a major problem encounteredly the agricultural pest controller. However, infestation can be detected latter when date palm trees almost completely destroyed. Accordingly, the incorporation of a specific insecticidal proteinase inhibitor gene to the genome of such trees can be helpful in pest control in the early stage of the insect.

Our finding showed that the partial purified TLE from midgut of RPW has molecular weight of approximately $24 \mathrm{kDa}$. using SDS-PAGE. The enzyme shows properties similar to those of the mammalian pancreatic trypsin, which is capable to hydrolyze casein as substrate and has the same molecular mass of $24 \mathrm{kDa}$ by electrophoretic analysis. To confirm the $24 \mathrm{kda}$ for TLE, we extended our analysis using SDS-PAGE zymography. The data cleary showed that $24 \mathrm{kDa}$ protein is capable to the substrate of serine proteases. On the other hand, the TLE shows properties similar to other serine proteolytic enzymes from many insects ${ }^{[13]}$ which is revealed highly proteolytic activity at basic $\mathrm{pH}$ in the range of 9.5-11 using radial diffusion analysis. Our data are consistent with those reported by ${ }^{[24]}$ who found that the major proteinase activity in the larval midguts of a common poplar tree borer, Anoplophora glabripennis motsch, were showed a $\mathrm{pH}$ optimum between 10 to 11.5 , suggesting a digestive system based largely on serine-like proteinases.

In addition, our data showed that the TLE from midgut of RPW was strongly inhibited by soybean trypsin inhibitor. This finding provide an important and useful information in implication with the biotechnology approach of transferring specific insecticidal proteinase inhibitor gene in palm trees and/or other economical plants.

\section{REFERENCES}

1. Al-Abdelmohsen, A.H., 1987. First registration of red palm weevil, Rynchophorus ferrugineus in Saudi Arabia. Agriculture in Arabian World 3: $15-16$.
2. Abraham, V.A., K.M. Abdulla koya and C. Kurian, 1989. Integrated management of red palm weevil Rhynchophorus ferrugineus. In coconut gardens. Paper presented at the 7 th Symposium on Plantation Crops, Coonoor, India, 16-19 October 1986. Journal of Plantation Crops 16, supplement, 159-162.

3. Gush, H., 1997. Date with disaster. The Gulf Today, September 29, p: 16.

4. Johnston, K.A., M.J. Lee, C. Brough, V.A. Hilder, A.M. Gatehouse and J.A. Gatehouse, 1995. Protease activities in the larval midgut of Heliothis virescens: Evidence for trypsin and chymotrypsinlike enzymes. Insect Biochem. Molecular Biology. 25: 375-383.

5. Masoud, S.A., L.B. Johnson, F.F. White and G.R. Reeck, 1993. Expression of a cysteine proteinase inhibitor in transgenic tobacco plants. Plant Mol. Biol. 21: 655-663.

6. Ryan, C.A., 1989. Proteinase inhibitor gene families: Strategies for transformation to improve plant defense against herbivores. Bioassays 10: 20-24.

7. Ryan, C.A., 1990. Protease inhibitors in plants: Genes for improving defense against insect and pathogens. Annu. Rev. Phytopath. 28: 425-449.

8. Hilder, V.A., A.M. Gatehouse, S.E. Sheerman, R.F. Barker and D. Boulter, 1987. A novel mechanism of insect resistance engineered into tobacco. Nature 330: 160-163.

9. Johnson, R., J. Narvaez, G. An and C. Ryan, 1989. Expression of proteinase inhibitors I and II in transgenic tobacco plants: Effects of natural defense against Manduca sexta larvae. Proc. Natl. Acad. Sci. USA 86: 9871-9875.

10. Wu, R., X. Duan and D. Xu, 1993. Analysis of rice genes in transgenic plants.Progress Nucleic Acid Res. Mol. Biol. 45: 1-26.

11. Duan X., X. Li, Q. Xue, M. Abo-El-Saad, D. Xu and $\mathrm{R}$. Wu, 1996a. Transgenic rice plants harboring an introduced potato proteinase inhibitor II gene are insect resistant. Nature Biotechnology14: 494-498.

12. Duan X., X. Li, Q. Xue, M. Abo-El-Saad, D. Xu and R. Wu, 1996b. Potato proteinase inhibitor II gene that confers insect resistance in transgenic rice plants. Rice genetics III Symposium, Manila, Philippines. pp: 318.

13. Abo-El-Saad, M., 2000. Trypsin-like enzyme from midgut of Spodoptera littoralis (Boisd): Biochemical identification and inhibition by insecticidal inhibitors. Alex. J. Pharma. Sci. 14:11-16. 
14. Ryan, C.A., 1967. Quantitative determination of soluble cellular proteins by radial diffusion in agar gels containing antibodies. Anal. Biochem. 19: 434-440.

15. Laemmli, U.K., 1970.Cleavage of structural proteins during the assembly of the head of bacteriophage T4. Nature 277: 680-685.

16. Garcia-Carreno, F.L., L.E. Dimes and N.F. Haard, 1993. Substrate-gel electrophoresis for composition and molecular weight of proteases or proteinaceous protease inhibitors. Anal. Biom. 214: 65-69.

17. Alarcon, F.J., T.F. Martinez, P. Barranco, T. Cabello, M. Diaz and F.J. Moyano, 2002. Digestive proteases during development of larvae of red palm weevil, Rhynchophorus ferrugineus (Olivier, 1790) (Coleoptera: Curculionidae). Insect Biochem. Mol. Biol. 32: 265-274.

18. Lacks, S.A. and S.S. Springhorn, 1980. Renaturation of enzyme after polyacrylamide gel electrophoresis in the presence of sodium dodecyl sulphate. J. Bio. Chem. 255: 7467-7473.

19. Bradford, M. 1976. A rapid and sensitive method for quantitation of microgram quantities of protein utilizing the principle of protein-dye binding. Anal. Biochem. 72: 248-254.
20. Valaitis, A.P., 1995. Gypsy moth midgut proteinases: purification and characterization of luminal trypsin, elastase and the brush border membrane leucine aminopeptidase. Insect Biochem and Molecular Biol. 25: 139-149.

21. Lee, M.J. and J.H. Anstee, 1995. Endoproteases from the midgut of larval Spodoptera littoralis include a chymotrypsin-like enzyme with an extended binding site. Insect Biochem and Molecular Biol. 25: 49-61.

22. Peterson, A.M, C.V. Barillas-Mury and M.A. Wells 1994.Sequence of three cDNAs encoding an alkaline midgut trypsin from Manduca sexta. Insect Biochem. Mol. Biol. 24: 463-471.

23. Borovsky, D., 1986. Proteolytic enzymes and blood digestion I the mosquito, Culex nigripalus. Arch. Insect Biochem. Physiol. 3: 147-160.

24. Bian, X., B.D. Shaw, Y. Han and J.T.Christeller, 1996. Midgut proteinase activities in larvae of Anoplophora glabripennis and their interaction with proteinase inhibitors. Arch.Insect Biochem. Physiol. 31: 23-37. 